\title{
Volatile Organic Compounds in the Po Basin \\ Part A: Anthropogenic VOCs
}

\section{Journal Article}

Author(s):

Steinbacher, M.; Dommen, J.; Ordóñez, C.; Reimann, S.; Grüebler, F.C.; Staehelin, J.; Prévôt, André S.H.

Publication date:

2005-07

Permanent link:

https://doi.org/10.3929/ethz-b-000031678

Rights / license:

In Copyright - Non-Commercial Use Permitted

Originally published in:

Journal of Atmospheric Chemistry 51(3), https://doi.org/10.1007/s10874-005-3576-1 


\title{
Volatile Organic Compounds in the Po Basin. Part A: Anthropogenic VOCs
}

\author{
M. STEINBACHER ${ }^{1,2}$, J. DOMMEN ${ }^{1}$, C. ORDONEZ ${ }^{1}$, S. REIMANN ${ }^{2}$, \\ F. C. GRÜEBLER ${ }^{3}$, J. STAEHELIN ${ }^{3}$ and A.S.H. PREVOT ${ }^{1}$ \\ ${ }^{1}$ Paul Scherrer Institut, Laboratory of Atmospheric Chemistry, CH - 5232 Villigen PSI, Switzerland, \\ e-mail: andre.prevot@psi.ch \\ ${ }^{2}$ Swiss Federal Institute for Material Testing and Research (EMPA), Laboratory for Air Pollution/ \\ Environmental Technology, $\mathrm{CH}-8600$ Dübendorf, Switzerland \\ ${ }^{3}$ Swiss Federal Institute of Technology, Institute for Atmospheric and Climate Science, \\ CH - 8093 Zurich, Switzerland
}

(Received: 13 May 2004; Accepted: 11 March 2005)

\begin{abstract}
Measurements of volatile organic compounds (VOCs) were performed in the Po Basin, northern Italy in early summer 1998 within the PIPAPO project as well as in summer 2002 and autumn 2003 within the FORMAT project. During the three campaigns, trace gases and meteorological parameters were measured at a semi-rural station, around $35 \mathrm{~km}$ north of the city center of Milan. Low toluene and benzene concentrations and lower toluene to benzene ratios on weekends, on Sundays, and in August enabled the identification of a 'weekend' and a 'vacation' effect when anthropogenic emissions were lower due to less traffic and reduced industrial activities, respectively. Recurrent nighttime cyclohexane peaks suggested a periodical short-term release of cyclohexane close to the semi-rural sampling site.

A multivariate receptor model analysis resulted in the distinction of different characteristic concentration profiles attributed to natural gas, biogenic impact, vehicle exhaust, industrial activities, and a single cyclohexane source.
\end{abstract}

Key words: benzene, Greater Milan area, positive matrix factorization, toluene, vacation effect, weekend effect

\section{Introduction}

Volatile organic compounds (VOCs) play a central role in the photochemistry of the atmospheric boundary layer. In the presence of sunlight and catalyzed by the oxides of nitrogen $\left(\mathrm{NO}_{x}\right)$, VOCs lead to the production of ozone $\left(\mathrm{O}_{3}\right)$ as already shown in the 1950s (Haagen-Smit, 1952). The VOCs present in the boundary layer are of anthropogenic as well as biogenic origin. On a global scale, biogenic emissions dominate, but in non-rural areas anthropogenic activities (particularly traffic and industrial processes) can provide large VOC emission sources that can lead to high hydrocarbon concentrations in the urban boundary layer. Due to their rather high maximum ozone incremental reactivity (Carter, 1994), the aromatics often affect the tropospheric ozone formation most even when the concentrations of other classes of 
compounds are higher (Sagebiel et al., 1996; Latella et al., 2005). Incomplete combustion of fossil fuels releases mostly hydrocarbons (alkanes, alkenes, aromatics), whereas organic solvents and their vapors also contain considerable amounts of oxygenated hydrocarbons (Friedrich and Obermeier, 1999). Aromatic compounds are often used as markers to identify the origin of the air masses (Winkler et al., 2002; Christensen et al., 1999) and are of particular interest due to their large abundance in motor vehicle emissions, their role in the ozone and aerosol formation (Seinfeld and Pandis, 1998; Kalberer et al., 2004), and their adverse health effects (Guerra et al., 1995) including benzene, which is rated as a human carcinogen.

The Milan area, located in the Po Basin is the most industrialized and densely populated region in Northern Italy (Neftel et al., 2002). Among the large urban areas in Europe, the Greater Milan area and the surrounding Po Basin are know as one of the regions that are most strongly affected by primary (Guerra et al., 1995) and secondary pollutants (Prévôt et al., 1997; Thielmann et al., 2001; Dommen et al., 2002). A high-resolution emission inventory for a weekday in May 1998 for the Po Basin revealed that stationary sources dominate the VOC emissions whereas the traffic emissions contribute half as much and biogenic emissions are only significant during the sunlight hours (Dommen et al., 2003). Besides the large emissions in this area, typical meteorological conditions characterized by frequent calm winds, thermal inversions, and high-pressure systems also favor the accumulation of atmospheric pollution (Bardeschi et al., 1991).

The presented measurements were part of the two field studies, Pianura Padana Produzione di Ozono (PIPAPO, ozone production in the Po Basin) and Formaldehyde as a Tracer of Oxidation in the Troposphere (FORMAT). The field experiment PIPAPO took place from May 06 to July 14, 1998 as a part of the EUROTRAC-2 subproject Limitation of Oxidation Production (LOOP) (Neftel et al., 2002). During this period, field measurements were performed at more than 30 ground stations between the city of Milan and the Alps north of Milan as well as on-board of a research aircraft. The project aim was the research on the evaluation of the temporal and spatial extent of the $\mathrm{VOC}$ and $\mathrm{NO}_{x}$ sensitivity of the ozone formation. Two of the main measurement sites during the PIPAPO campaign were Bresso and Verzago, both located north of downtown Milan. VOC data were available for 56 days in Verzago and 42 days in Bresso. The hydrocarbon measurements of PIPAPO were analyzed by Grüebler (1999).

The main objective of the FORMAT project is to obtain a better knowledge of the regional distribution of formaldehyde (HCHO) in the Po Basin. HCHO is an important intermediate of the VOC oxidation and a source of oxidizing radicals. Measurements were conducted at three ground-based stations and on-board of two aircrafts and a microlight research aircraft. Two of the measurement sites (Bresso and Verzago) were identical with the ground stations during PIPAPO 1998. Observations were performed in late summer 2002 (July 22 to September 03) and in autumn 2003 (September 12 to October 6). VOC measurements were available for 35 and 17 days in 2002 and 2003, respectively. 
In this paper we present, analyze, and compare the available measurements of individual anthropogenic hydrocarbons focusing on the relation to emission sources. In the companion paper (Steinbacher et al., 2005), we study biogenic VOCs of these campaigns.

\section{Measurement Sites, Techniques, and Meteorological Conditions}

\subsection{MEASUREMENT SITES}

The measurements presented in this work were performed at Verzago, around 35 $\mathrm{km}$ north of the city center, and at Bresso, approximately $5 \mathrm{~km}$ north of downtown Milan. The measurement site at Verzago was situated in a semi-rural environment. The measurement containers were placed at the border of a corn field outside a small village. Local anthropogenic emissions originated only from a small blind alley passing the measurement containers and a few houses nearby. The nearest major road that connects Como and Bergamo was located one kilometer northeast of the measurement site. The surrounding area was patchy with fields, meadows, forests, and small villages. Thus, the local environment was not homogeneous with respect to biogenic and anthropogenic emissions.

The measurements at Bresso were carried out on a private airfield inside the freeway belt around Milan, within a densely populated suburb of the city with some light industry. Road traffic and two close gas stations were the main local anthropogenic emission sources. Vehicle emissions were present at nearly every time of the day due to heavy traffic on the highway and another main road just $50 \mathrm{~m}$ west of the airfield.

In summer, the topography leads to orographically and thermally induced valley winds. Consequently, southerly winds prevail during daytime between Milan and the Alpine foothills. Therefore, Po Basin air is advected towards the Alps, the Milan plume drifts north into the direction of Switzerland and Verzago is often located downwind of Milan during daytime in summer (Prévôt et al., 1997; Staffelbach et al., 1997; Thielmann et al., 2002).

\subsection{TRACE GAS MEASUREMENTS}

\subsubsection{GC-FID (Airmotec HC1010)}

A commercial Airmotec HC1010 gas chromatograph (Konrad and Volz-Thomas, 2000) (ChromatoSud, Saint Antoine, France) was used in 1998 (at Bresso and Verzago) (Grüebler, 1999) and 2002 (at Verzago) to measure hydrocarbons between $\mathrm{C}_{4}$ and $\mathrm{C}_{10}$. Sample air is pulled through adsorption tubes containing Carbopack $\mathrm{B}$ and Carbosieve III. After thermal desorption, the hydrocarbons are cryofocused using a fused silica capillary packed with Carbopack B and cooled with $\mathrm{CO}_{2}$. Injection onto the chromatographic column proceeds after fast desorption at $350^{\circ} \mathrm{C}$. The stationary phase of the separation column consists of $2.5 \%$ phenyl- and $97.5 \%$ 
methylpolysiloxan (BGB Analytik AG, Anwil, Switzerland). A flame ionization detector (FID) is used for detection and quantification. A measuring cycle consisted of 29 min sampling, 1 min transferring the sample to the capillary column, and 9 min for chromatography. A new sample can be drawn while analyzing the previous sample. Therefore, quasi-continuous measurements with 30 min time resolution were conducted. In 1998, elaborate calibrations and intercomparisons were conducted before and after the campaign (Grüebler, 1999). During the campaign, a benzene standard was used for calibration (Thielmann et al., 2001). In 2002, calibrations were performed in the field with a gas standard containing alkanes, alkenes, alkynes, dialkenes, and aromatics $\leq \mathrm{C}_{9}$ at concentrations of a few ppb (National Physical Laboratory, Teddington, UK) and a benzene standard of $750 \mathrm{ppb}$ (BOC Gase, Multigas, Bienne, Switzerland).

\subsubsection{PTR-MS (Ionicon Analytik)}

A proton transfer reaction mass spectrometer (PTR-MS) was used for VOC measurements at Verzago in 2002. The measuring method is based on a proton-transfer reaction of hydronium ions $\left(\mathrm{H}_{3} \mathrm{O}^{+}\right)$to compounds with a higher proton affinity than water taking place in a drift-tube reactor, and subsequent detection of the product ions in a quadrupole mass spectrometer (Balzers QMG422). Most common volatile organic compounds in the atmosphere, excluding the alkanes and small alkenes/alkynes, exhibit sufficient high proton affinities (NIST Chemistry webbook, 2004). The proton-transfer takes place at relatively low energies and therefore causes only little fragmentation of most of the ion products. The whole inlet system both outside and inside the instrument was made out of Silcosteel ${ }^{\circledR}$ (Restek, Bellefonte, U.S.A.) tubes. The inlet tubing, as well as the tubing in the instrument and the drift-tube were temperature stabilized to $50{ }^{\circ} \mathrm{C}$ to improve the instrument stability and to minimize the variability of the background signal (Steinbacher et al., 2004). The background signal was measured every 3 hours for 30 min using an activated charcoal cartridge in the sampling line. In the default mode, 30 selected masses were measured, each of them with a dwell time of $10 \mathrm{~s}$, resulting in a cycle time of $4 \frac{1}{2} \mathrm{~min}$. Four times a day full scans from 20 amu up to $150 \mathrm{amu}$ (dwell time per mass $2 \mathrm{~s}$ ) were conducted. One full scan cycle took around $4 \frac{1}{2} \mathrm{~min}$. Due to the proton transfer, VOCs are usually identified at their parent mass +1 . Thus, benzene and toluene were measured at $\mathrm{m} / \mathrm{z} 79$ and $\mathrm{m} / \mathrm{z} 93$, respectively. However, because of the lack of chromatographic separations, isomers can not be quantified individually. Calibrations were performed with the same standards as used for the Airmotec GC-FID calibration in 2002.

\subsubsection{GC-FID (Varian 3400)}

For the analysis of VOCs between $\mathrm{C}_{2}$ and $\mathrm{C}_{7}$ in the FORMAT campaign 2003, a gas chromatograph equipped with a flame ionization detector (GC-FID, Varian 
3400) was used. VOCs from $200 \mathrm{ml}$ of air were enriched on a cooled microtrap $\left(-30{ }^{\circ} \mathrm{C}\right)$ by a thermodesorber (Perkin-Elmer, Turbomatrix) at a flow rate of 10 $\mathrm{ml} / \mathrm{min}$ during $20 \mathrm{~min}$. After trapping, VOCs were introduced directly into the GC by conductive heating of the trap to $250{ }^{\circ} \mathrm{C}$ at $40{ }^{\circ} \mathrm{C} / \mathrm{min}$. Analysis was performed on an $\mathrm{Al}_{2} \mathrm{O}_{3} / \mathrm{KCl}$ PLOT column $(50 \mathrm{~m} \times 0.53 \mathrm{~mm}$ i.d.) with $\mathrm{He}$ as carrier gas. Calibration runs were made every week with a 30 -component standard in the ppb range (NPL, Teddington, U.K.).

\subsubsection{Other Trace Gas and Aerosol Measurements}

Apart from the organic compounds and meteorological parameters, a wide range of inorganic compounds (carbon monoxide, ozone, nitrogen oxides, other reactive nitrogen, radon) and aerosols were measured during the different campaigns. Species of interest within this work are most of all ozone, nitrogen oxides, and carbon monoxide. Ozone was measured by UV absorption (Environics) and nitrogen oxides by ozone chemiluminescence (Eco Physics, MonitorLabs). In 2002, nitrogen dioxide was measured by luminol chemiluminescence (for details see Dommen et al. (2002)). CO was measured at Verzago in 1998 with a conventional non-dispersive infrared detector (Horiba), in 2002 and 2003 by UV-vacuum fluorescence (AeroLaser). Meteorological parameters like temperature, wind speed and direction, humidity, and radiation were measured during the three campaigns.

\subsection{METEOROLOGICAL CONDITIONS AND OZONE CONCENTRATIONS}

A description of the meteorological conditions during the PIPAPO campaign is given by Neftel et al. (2002). Besides the two intensive observation periods (May 12-13 and June 1 to 10, 1998) with sunny conditions, a third sunny and warm period due to a high pressure system over western Europe occurred from June 16 to June 23. During the last period, maximum temperatures reached up to $30{ }^{\circ} \mathrm{C}$, and ozone levels rose to $145 \mathrm{ppb}$ at Verzago whereas maximum $\mathrm{O}_{3}$ mixing ratios of up to $150 \mathrm{ppb}$ and $200 \mathrm{ppb}$ were detected at Bresso and Verzago, respectively, during the first intensive period (Spirig et al., 2002; Thielmann et al., 2002).

During FORMAT 2002, three fair weather periods were encountered. The first period appeared from July 22 to July 30, the second from August 6 to 8, and the third from August 12 to 18 . Ozone mixing ratios stayed always below $95 \mathrm{ppb}$, even when afternoon temperatures reached $30{ }^{\circ} \mathrm{C}$, reflecting a generally less polluted boundary layer.

The FORMAT campaign 2003 started with a foehn event on September 12 followed by stable anticylonic conditions associated with a ridge stretched from Eastern Europe towards North Africa at high and mid levels. Meteorologically stable conditions prevailed until September 22 when a trough passed the Po Basin, which resulted in a drop of the afternoon maximum temperature from $28.2{ }^{\circ} \mathrm{C}$ (September 21) to $21.7^{\circ} \mathrm{C}$ (September 23). Within the same period, afternoon maximum ozone 
mixing ratios dropped from $132 \mathrm{ppb}$ to $44 \mathrm{ppb}$. The highest ozone mixing ratios were observed on September 20 with 138 ppb.

\section{Results and Discussion}

\subsection{AROMATIC COMPOUNDS}

Figures 1 and 2 show typical time series of aromatic compounds during the campaigns in 1998 and 2003. A distinct toluene peak occurred usually around noontime, also accompanied by elevated $\mathrm{C}_{2}$-benzene levels (not shown; usually, the mixing ratios of the $\mathrm{C}_{2}$ - and $\mathrm{C}_{3}$-benzenes in 1998 stayed below $2 \mathrm{ppb}$ and well below 500 ppt, respectively) whereas the benzene concentrations stayed nearly constant. The peaks appeared during south-southwesterly winds with wind speeds between 1.5 and $2.5 \mathrm{~m} / \mathrm{s}$ in 1998 and between 1 and $2 \mathrm{~m} / \mathrm{s}$ in 2003. Several reasons point to an industrial release as the origin of these midday peaks. Firstly, we assume that industrial activities take place during the working days but not during weekends. Similar meteorological conditions prevailed on Sunday, 21 June 1998 and Sunday, 21 September 2003 but comparable peaks were not detected. Secondly, the use of benzene as a solvent is forbidden in Italy, which could explain the low benzene levels even when the other aromatics were high. Thirdly, aromatic emissions from traffic usually show a good correlation between benzene and toluene as it is observed for Bresso in 1998 (see Figure 3, small panel). Figure 3 also shows a characteristic 6-day time series for benzene and toluene at Bresso. Usually, the

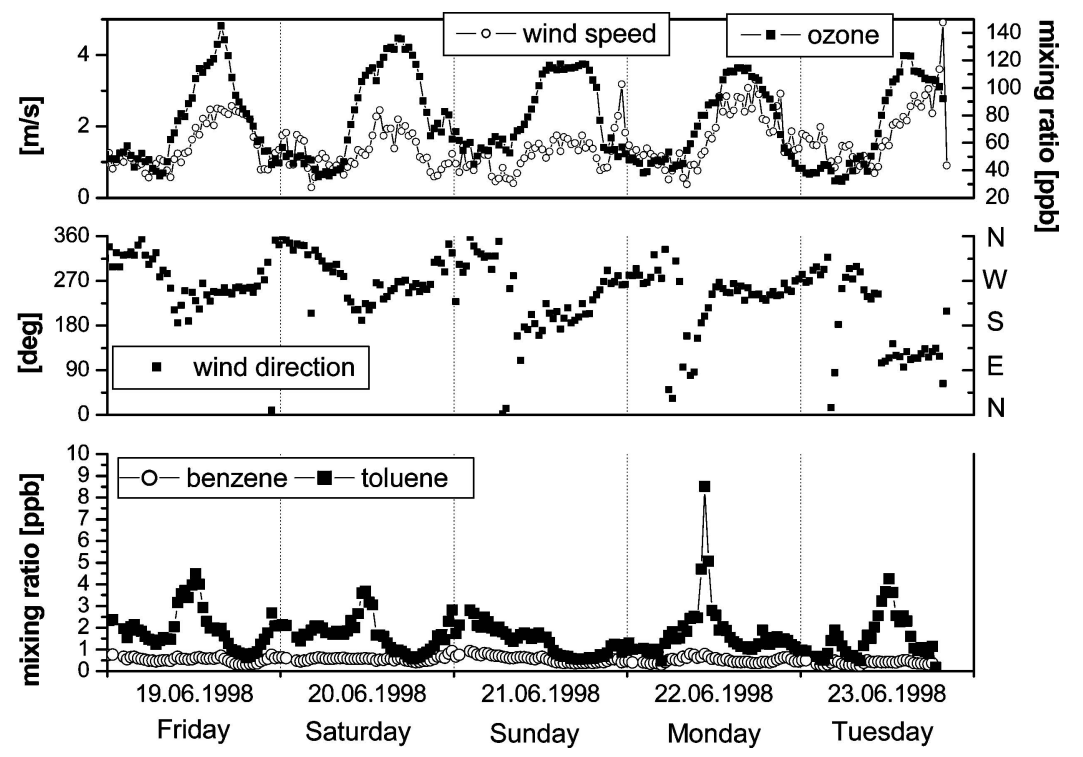

Figure 1. Time series of wind speed, ozone, wind direction, and aromatic compounds at Verzago measured with GC-FID in 1998. 


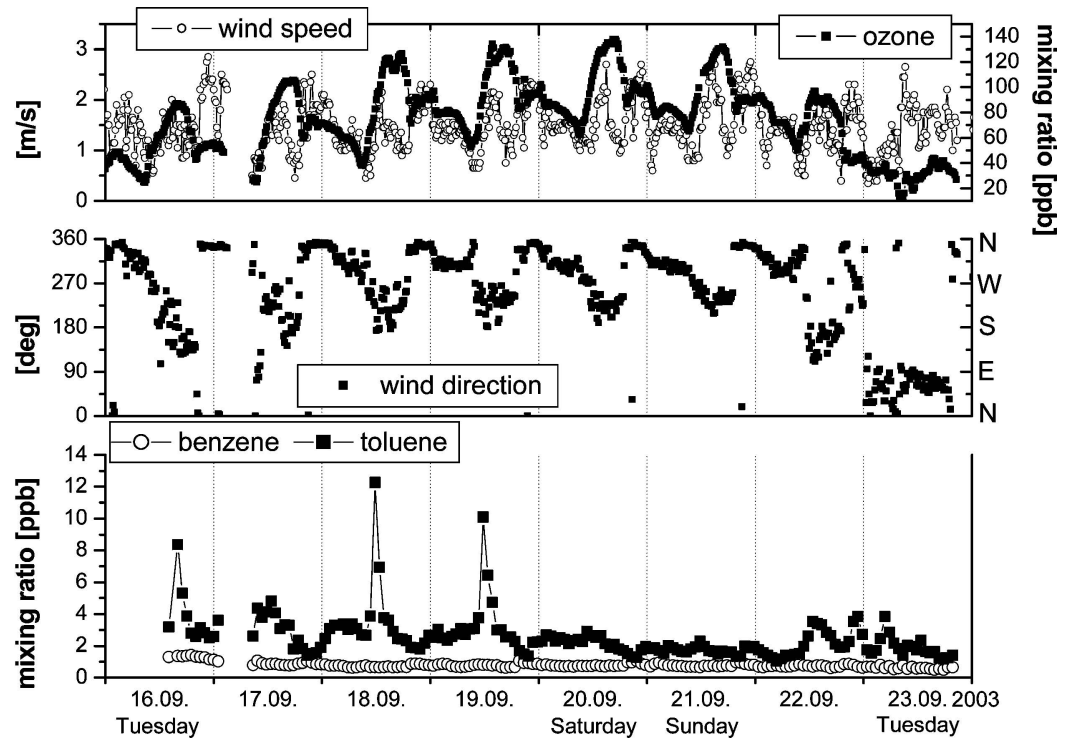

Figure 2. Time series of wind speed, ozone, wind direction, benzene, and toluene at Verzago measured with GC-FID in 2003.

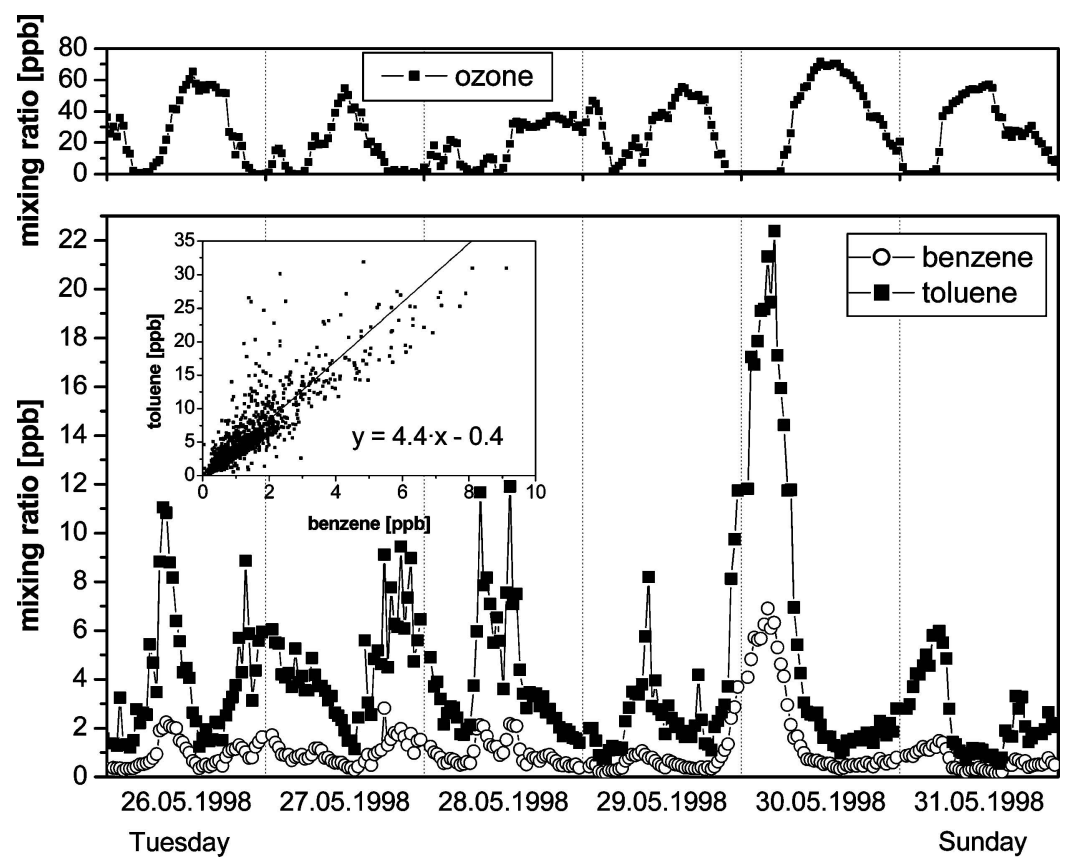

Figure 3. Big panel: 6-day time series of benzene and toluene at Bresso in 1998. Small panel: scatterplot of toluene and benzene for the whole PIPAPO campaign (May 12 to July 14, 1998). The slope of the orthogonal regression line is $4.4\left(R^{2}=0.8\right)$. Upper panel: time series of ozone. 
highest mixing ratios of anthropogenic VOCs were found during the night due to an accumulation of traffic emissions close to the measurement site in the shallow nocturnal boundary layer. An extreme event was observed in the early morning of 30 May 1998. In contrast to Verzago, the benzene mixing ratios are well correlated with the other aromatics even during the day (e.g. see the simultaneous peaks of benzene and toluene on 28 May) supporting the hypothesis of traffic emissions as the main source. Nevertheless, it should be mentioned that the toluene to benzene ratio reflected by a slope higher than 4 in Figure 3 is twice the ratio of the corresponding emission factors derived from a tunnel study in Switzerland in 1993 (Staehelin et al., 1998). Ciccioli et al. (1999) observed in the Greater Rome Area during a 2 days case study in 1991 toluene/benzene mixing ratio ratios of 1.9 to 2.8 and 1.6 to 1.8 in the urban and in the suburban area, respectively. In Italy, the benzene content in the gasoline was limited by law to $1 \%$ already in 1998 (Dommen et al., 2003; Grüebler, 1999), whereas fuel with up to $5 \%$ benzene was allowed in Switzerland at the same time. The mean benzene content of the Swiss car fleet constituted 2.3\% in 1993 (Heeb et al., 2000). In the beginning of 2000, restrictions to $1 \%$ benzene content were also implemented in Switzerland resulting in a toluene/benzene increase from 1.7 to 3.4 in Duebendorf, a suburban sampling site close to Zurich, between 1998 to 2001 .

Analyzing the benzene to toluene scatterplot for Verzago in 1998 (see Figure 4), a lower correlation than in Bresso is recognizable. Due to the longer lifetime of benzene compared to toluene (Seinfeld and Pandis, 1998), it would be expected to detect lower toluene to benzene ratios if the traffic emissions are farther away from the measurement site due to the ageing of the air mass. However, higher toluene to benzene ratios (slope of 7.7) were found around noontime (11 AM to 2 PM) in line with the interpretation of the advection of industrial emissions at this time. A slope of 4.7 for all other cases is comparable to the ratio at Bresso and to data obtained from the Regione Lombardia (Direzione Generale Qualità dell'Ambiente, http://www. ambiente.regione.lombardia.it/webqa/aria/Archivio.htm) close to roads. We also distinguished between weekdays and Saturday and Sunday (Figure 4b). It is obvious that the lowest toluene to benzene ratios and the highest correlation without any enhanced toluene mixing ratios were found on Sundays. A slightly higher slope with a few cases of elevated toluene mixing ratios was measured on Saturdays whereas the largest scatter and most of the data with high toluene to benzene ratios were observed on weekdays. Until now, the weekend effect for ozone (partly in combination with other air pollutants like $\mathrm{CO}$ and total VOCs) is well documented (Brönnimann and Neu, 1997; Diem, 2000; Jenkin et al., 2002; Marr and Harley, 2002; Heuss et al., 2003). However, there are only a few studies on the weekend effect on certain VOC species. Blanchard and Tanenbaum (2003) showed for 10 sites in California that the benzene and toluene levels are considerably reduced on weekends, especially on Sundays. Figure 4b nicely reveals that a 'weekend effect' in the toluene to benzene ratios can be detected despite the limited number of data during a 70-day field campaign. 

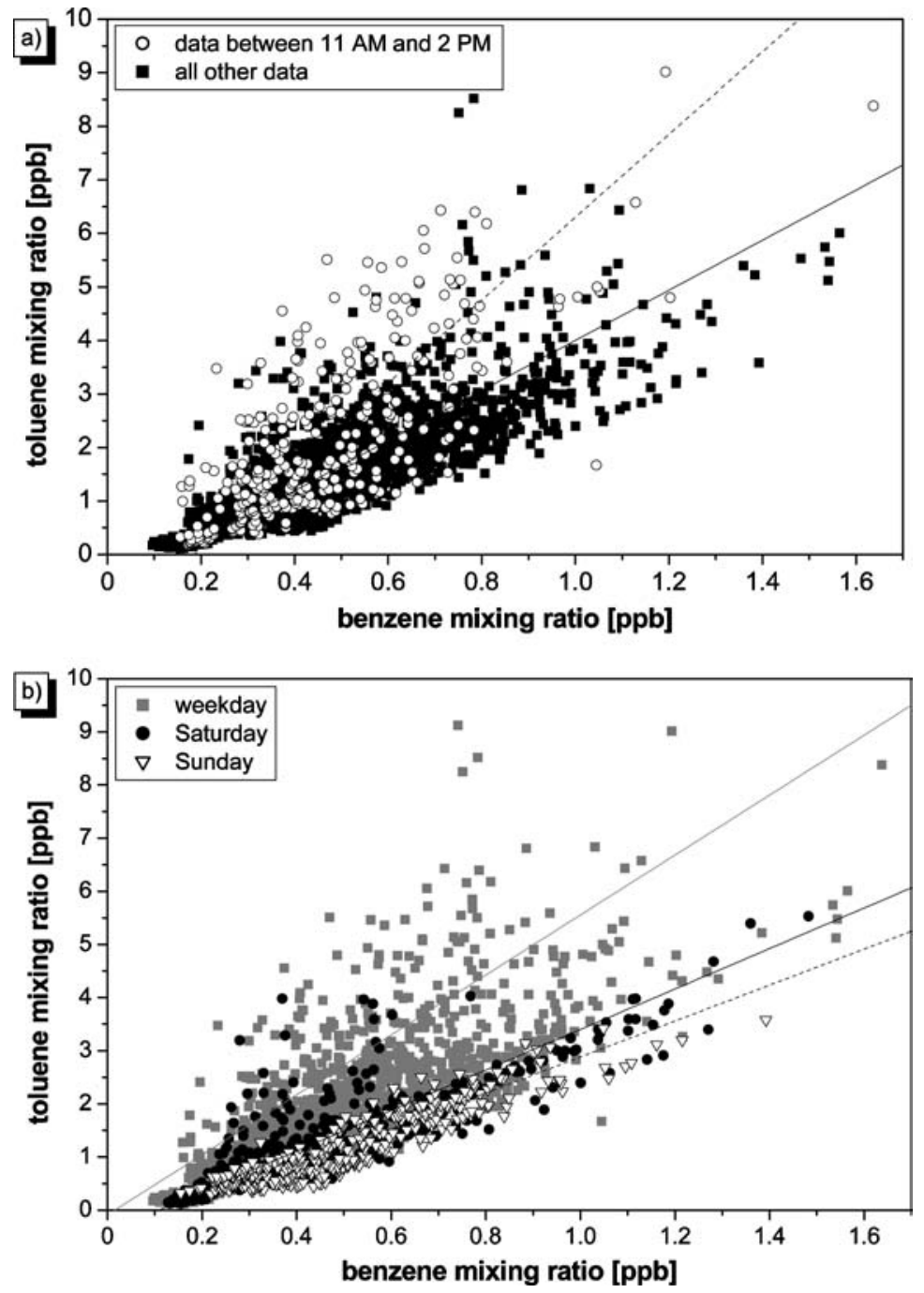

Figure 4. Scatterplot of toluene vs. benzene at Verzago in 1998. Panel a) distinction of cases around noontime (11 AM to $2 \mathrm{PM}$ ) and other daytimes. The slopes of the orthogonal regression line are 7.7 and 4.7 for $11 \mathrm{AM}$ to $2 \mathrm{PM}$ data (dashed line, $R^{2}=0.53$ ) and the rest of the data (solid line, $R^{2}=0.64$ ), respectively. Panel b) distinction of weekday, Saturday, and Sunday cases. The slopes of the orthogonal regression lines are 5.6 (weekday, grey line, $R^{2}=0.59$ ), 3.8 (Saturday, solid black line, $R^{2}=0.70$ ), and 3.4 (Sunday, dashed line, $R^{2}=0.85$ ).

Figure 5a shows a corresponding plot to Figure 1 for mid-August 2002. In contrast to 1998, the VOCs were measured by PTR-MS. The black horizontal bars stress the periods with the conditions that prevailed in 1998 when toluene peaks around noontime occurred. It is obvious that on average no similar behavior could be detected within the presented period except at the end of the 2002 campaign, when 

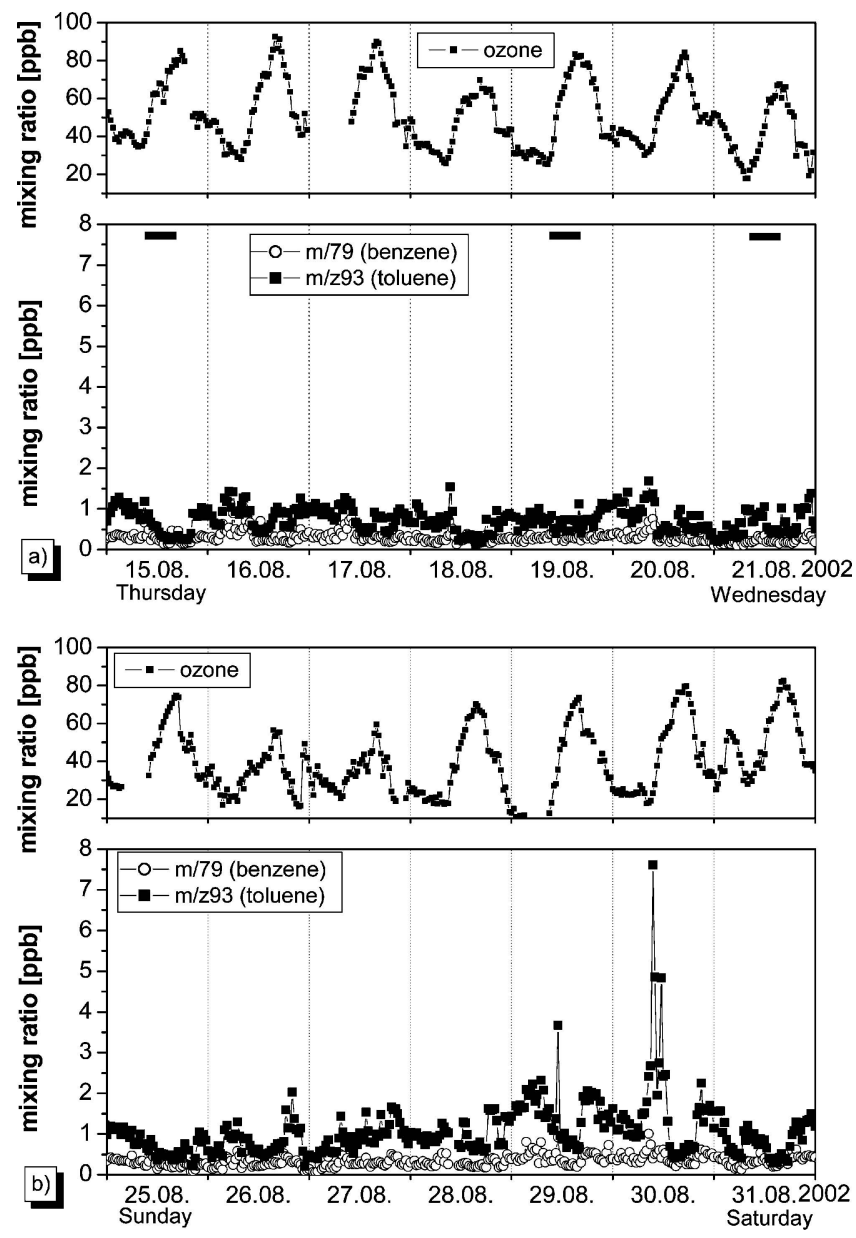

Figure 5. Time series of ozone, $\mathrm{m} / \mathrm{z} 79$ (protonated benzene) and m/z93 (protonated toluene) at Verzago measured with PTR-MS in 2002. Panel a) August 15 to 21. Panel b) August 25 to 31.

such peaks were observed again as it is seen in Figure $5 b\left(\mathrm{C}_{2}\right.$-and $\mathrm{C}_{3}$-benzenes were usually below $500 \mathrm{ppt}$ and $200 \mathrm{ppt}$, respectively. The sum of $\mathrm{C}_{3}$-benzenes measured with the PTR-MS exceeded only rarely $500 \mathrm{ppt}$ ). That seems to be a result of the 'ferragosto', the Italian vacation time effect in mid-August, when industrial activities and traffic are considerably reduced because by the end of August the vacation time is terminated in this area. This effect is also corroborated by different slopes of the toluene versus benzene plot that reveals the different conditions during the 3 weeks in mid-August (see Figure 6). The slopes at the beginning and at the end of August are nearly identical whereas the slope in between is considerably lower. The meteorological conditions were similar during the first and the second period and no considerably different ozone levels were found. 


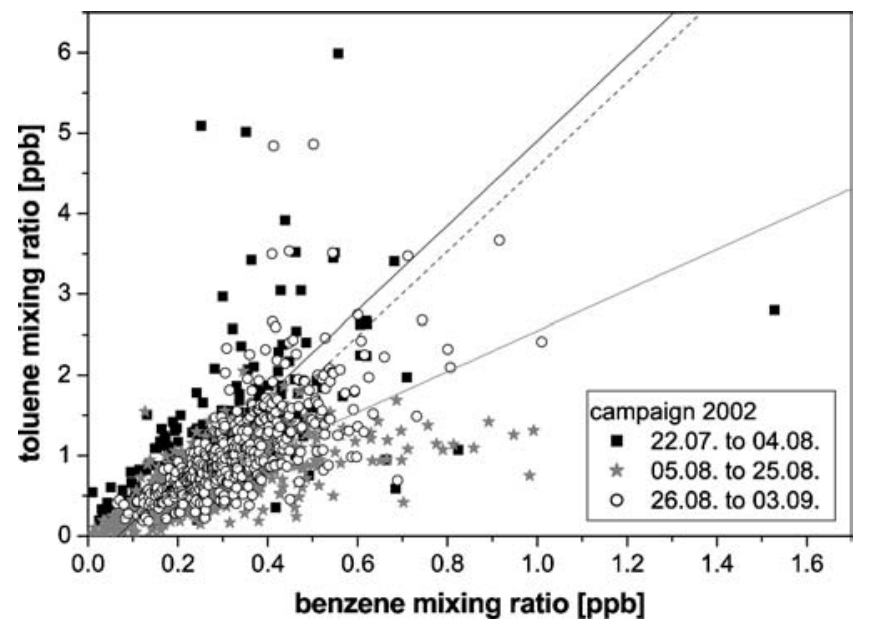

Figure 6. Toluene to benzene scatterplot for the 2002 campaign. Different periods are characterized by different symbols. The slopes of the orthogonal regression line are 5.3 for the first $\left(R^{2}=0.36\right.$; solid black line $)$ and the third period $\left(R^{2}=0.40\right.$; dashed black line $)$ and 2.5 for the second period $\left(R^{2}=0.43\right.$; grey line).

Therefore a strong bias due to different photochemical oxidation capacities of the atmosphere is not expected. Consequently, a different emission pattern (due to different industrial activities) is likely to be responsible for the different toluene to benzene ratios. The mean toluene/benzene ratios are 3.9, 2.7, and 3.2 for the first, the second, and the third period, respectively. Perennial benzene and toluene data from the Direzione Generale Qualità dell'Ambiente, Regione Lombardia for measurement sites close to traffic emissions in the Po Basin show considerably reduced benzene and toluene mixing ratios in August, too, as well as significant changes (> 99.9\%; two-population (independent) t-test) in the toluene to benzene ratio similar to the ones observed at Verzago. The mean afternoon (10 AM to 6 PM) benzene and toluene mixing ratios dropped in Como (Viale Cattaneo), Monza (Via Elvezia), and Milano (Via de Vincenti) from July to August as listed in Table I. At Verzago, the mean benzene ratios were already low in July and no reduction in the mean benzene was observed. The slightly smaller decrease of the ratio at the three traffic dominated sampling sites compared to our semi-rural site could be explained by a more dominating industrial impact (including a reduced industrial impact in mid-August) at Verzago. Similar observations with significantly reduced toluene concentrations and rather constant benzene levels in August compared to July were already published for a two years dataset in Rome but were not explicitly related to a changed emission pattern during the summer holidays (Brocco et al., 1997).

Table II summarizes a compilation of toluene to benzene ratios at Verzago for the three campaigns and the two different effects discussed above. On the one hand, the lowest toluene to benzene ratios were always measured on Sundays, and the 
Table I. Mean afternoon (10 AM to 6 PM) toluene and benzene mixing ratios (in ppb), and toluene to benzene ratios for July and August

\begin{tabular}{|c|c|c|c|c|c|c|}
\hline \multirow[b]{2}{*}{ Station } & \multicolumn{3}{|c|}{ July } & \multicolumn{3}{|c|}{ August } \\
\hline & Toluene & Benzene & $\begin{array}{l}\text { Toluene/ } \\
\text { Benzene }\end{array}$ & Toluene & Benzene & $\begin{array}{l}\text { Toluene/ } \\
\text { Benzene }\end{array}$ \\
\hline Como $^{\mathrm{a}}$ & 8.5 & 1.9 & 4.8 & 6.6 & 1.5 & 4.4 \\
\hline Monza $^{\mathrm{a}}$ & 7.5 & 1.5 & 7.1 & 4.7 & 1.1 & 5.3 \\
\hline Milano $^{\mathrm{a}}$ & 3.9 & 1.1 & 3.5 & 2.4 & 0.9 & 2.7 \\
\hline Verzago & $0.8^{\mathrm{b}}$ & $0.3^{\mathrm{b}}$ & $3.9^{\mathrm{b}}$ & $0.6^{\mathrm{c}}$ & $0.3^{\mathrm{c}}$ & $2.3^{\mathrm{c}}$ \\
\hline
\end{tabular}

a Obtained from the Direzione Generale Qualità dell'Ambiente, Lombardia.

b22 July to 04 August 2002.

'05 August to 25 August 2002. Como, Monza, and Milano data were available from 1996-2003, 2000-2003, and 2001-2002, respectively.

Table II. Mean ( \pm standard error of the mean) toluene to benzene ratios at Verzago on weekdays, Saturdays, and Sundays for the three different campaigns

\begin{tabular}{llll}
\hline & \multicolumn{3}{c}{ Toluene/Benzene ratio } \\
\cline { 2 - 4 } Campaign & Weekday & Saturday & Sunday \\
\hline PIPAPO 1998 & $3.77 \pm 0.04$ & $2.84 \pm 0.07$ & $2.30 \pm 0.03$ \\
FORMAT 2002, all & $3.26 \pm 0.11$ & $2.89 \pm 0.08$ & $2.57 \pm 0.07$ \\
FORMAT 2002, 05.08. to 25.08. & $2.73 \pm 0.06$ & $2.87 \pm 0.10$ & $2.50 \pm 0.08$ \\
FORMAT 2002, rest & $3.59 \pm 0.18$ & $2.92 \pm 0.12$ & $2.66 \pm 0.10$ \\
FORMAT 2003 & $3.35 \pm 0.11$ & $3.21 \pm 0.11$ & $2.13 \pm 0.08$
\end{tabular}

The campaign in 2002 is additionally split into two periods to emphasize the 'ferragosto effect'.

highest on weekdays. On the other hand, the toluene to benzene ratios in midAugust 2002 were similar on weekdays and on weekends, confirming the reduced industrial emissions during that month.

\subsection{CYCLOHEXANE}

The behavior of cyclohexane suggests also a significant industrial source (Figure 7). The background mixing ratios between 25 and $200 \mathrm{ppt}$ are in a good agreement with data observed in the suburban area of Rome (Ciccioli et al., 1999). During most of the nights, distinct cyclohexane peaks up to 9 ppb appeared between 9 and 10 PM whereas levels usually below $500 \mathrm{ppt}$ were observed during the rest of the day. No peaks were measured at weekends, which points again to an industrial release. 


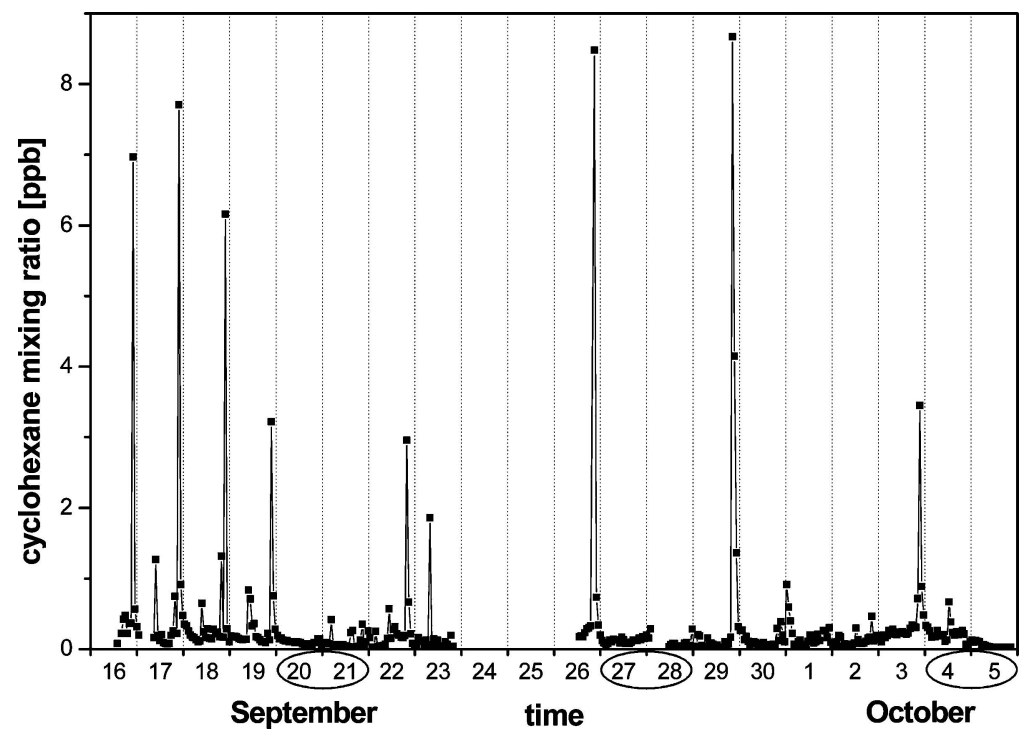

Figure 7. Time series of cyclohexane at Verzago measured with GC-FID in 2003. Weekends are marked with ellipses.

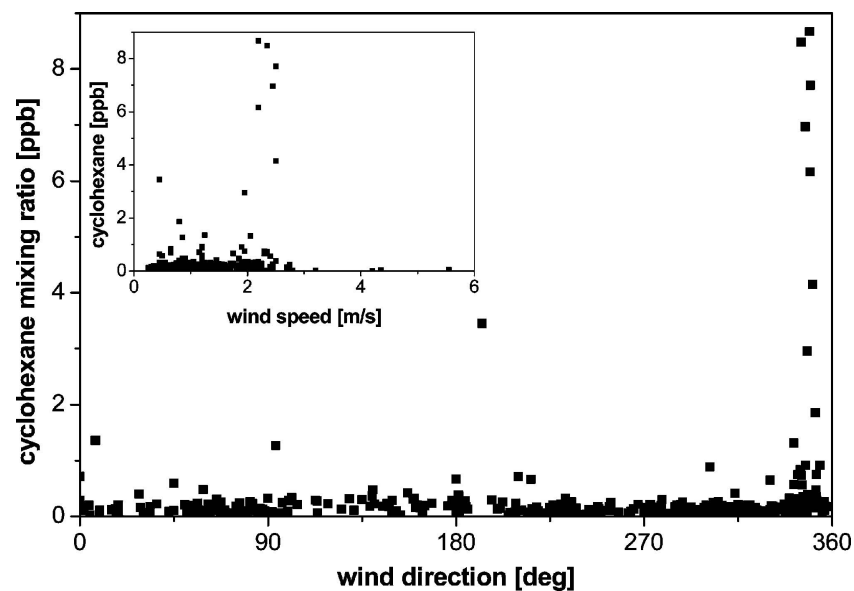

Figure 8. Scatterplot of cyclohexane versus wind direction (big panel) and wind speed (small panel) for the 2003 field campaign.

Cyclohexane is used for the manufacture of nylon, the production of synthetic fibers and as a solvent in varnishes, resins, and stain removers. The Air Resources Board (http://www.arb.ca.gov) reported primary stationary sources in California from petroleum refining, automotive repair shops, and commercial printing and publishing. Figure 8 shows the correlation between the wind conditions and the cyclohexane mixing ratios. It reveals that the point source is located in the north 
and the mixing ratios are advected most efficiently with wind speeds between 2 and $3 \mathrm{~m} / \mathrm{s}$. In contrast to peaks of ethene and propene coincident with the turn of the wind direction from west to north (see the companion paper (Steinbacher et al., 2005)), the cyclohexane peaks appeared around 1 to $2 \mathrm{~h}$ after the change of the wind direction showing that sources for cyclohexane and the alkenes were different. Like the source of the alkenes, the emission source of cylohexane is also located in the north. The short and narrow peaks of cyclohexane suggest a point source within a couple of kilometers, most probably between the sampling site and the Alpine foothills in the north. Assuming a wind speed of $1.5 \mathrm{~m} / \mathrm{s}$ and considering the time of 1 to $2 \mathrm{~h}$ after the wind turn, the maximum distance is $10 \mathrm{~km}$. It points to a periodical short-term release of cyclohexane possibly at the end of a production process.

\subsection{RECEPTOR MODELING USING POSITIVE MATRIX FACTORIZATION ANALYSIS}

A multivariate receptor model was employed for air pollution concentration apportionment. Such statistical analysis allows attributing the variabilities of trace gas measurements to different concentration profiles. The commonly used method of Chemical Mass Balance models needs a priori knowledge of the individual source profiles, which is often not available (Watson et al., 2001). Here we use so called 'Positive Matrix Factorization' (PMF), a variant of factor analysis with non-negative factor elements (Paatero and Tapper, 1994; Paatero, 1997) in order to analyze the measurements of 2003. The results indicate that five different profiles were required to fit the field measurements to identify and distinguish various striking concentration profiles (see Figure 9). Concentration profile \#5 is obviously determined by the cyclohexane concentration. This profile does not contain any substantial contribution of another species, revealing that only cyclohexane is emitted by this certain industrial process. The diurnal pattern of the contribution to profile \#5 (see Figure 10) nicely represents the diurnal cyclohexane pattern. Concentration profile $\# 2$ is the only profile with a substantial isoprene concentration. As the diurnal cycle of the contribution to profile \#2 (see Figure 10) looks quite similar to the real isoprene cycle (see the companion paper (Steinbacher et al., 2005)), this profile can be attributed to a biogenic impact. Profile \#3 is identified as the vehicle exhaust (tailpipe) concentration profile. It shows a toluene to benzene ratio of 2.5 (in good agreement with the Sunday toluene/benzene traffic ratio, see Table II), and a high ethane, ethyne, and propene concentration that is characteristic for vehicle exhaust emissions (Borbon et al., 2003). In addition, our attribution is also confirmed by studies from the United States performed in road tunnels (Sagebiel et al., 1996), receptor model and emissions inventory source apportionment studies within the San Joaquin Valley Air Quality Study/Atmospheric Utilities Signatures, Predictions, and Experiments Regional Model Adaptation Program (SARMAP) (Fujita et al., 1995), the Paso del Norte Ozone Study (Fujita 2001), and source apportionment studies by chemical mass balance (Watson et al., 2001). The lower toluene to benzene ratios compared to the data observed at Bresso reveal that photochemically 


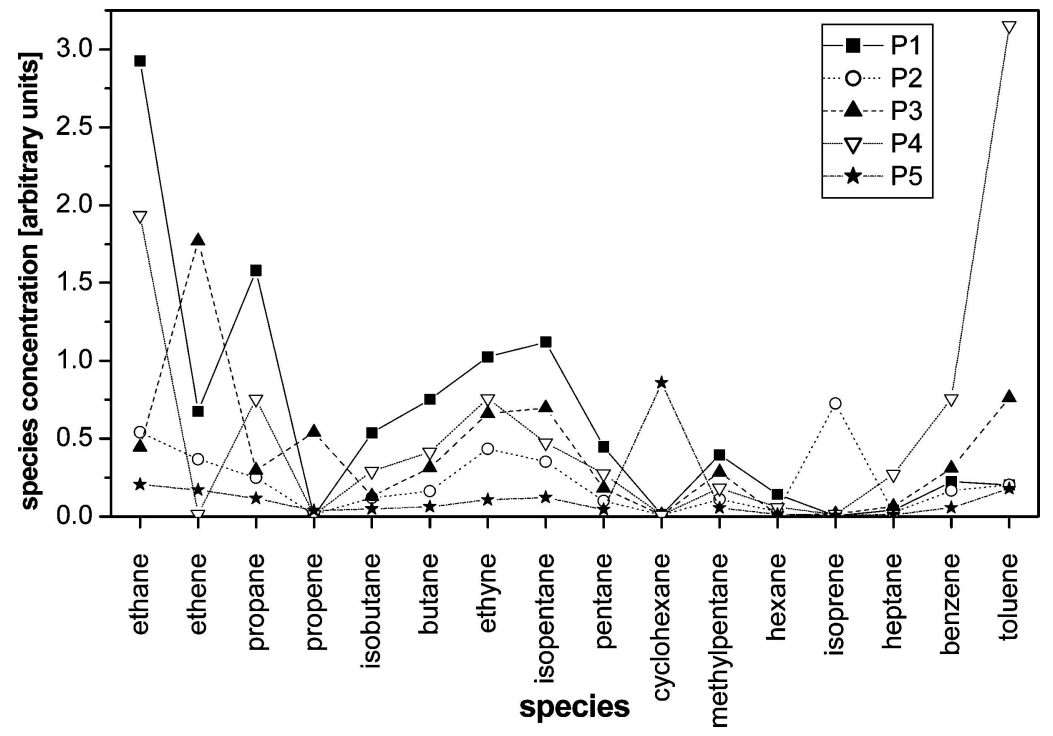

Figure 9. Concentrations profiles of the positive matrix factorization analysis applied to the VOC dataset measured in 2003. Methylpentane represents the sum of 2-methylpentane and 3-methylpentane.

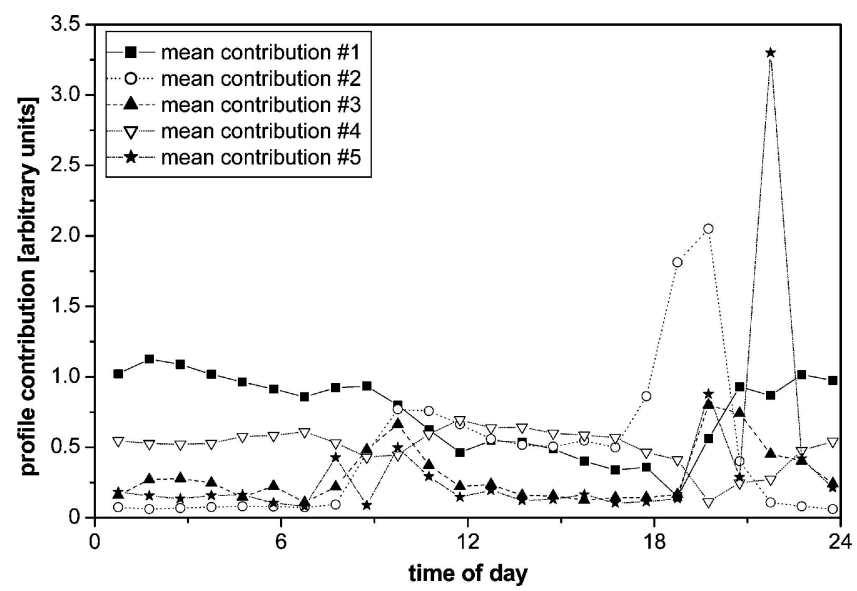

Figure 10. Mean diurnal cycle of the profile contributions for the period from September 17 to 23,2003 .

aged air masses are predominantly analyzed at Verzago. Furthermore, the profile contribution is significantly correlated with carbon monoxide $(\mathrm{CO})(R=0.73$, $n=315$ ), a good marker for traffic emissions that was not included in the PMF analysis. The profiles \#1 and \#4 only differ by the high toluene contribution in \#4 and the different diurnal pattern. Profile \#1 decreases in the afternoon while profile 4 increases. Therefore we attribute profile \#1 to a constant emission source 
whereby the diurnal variation reflects the inverse daily cycle of the mixing height. The composition of profile \#1 is indicative of natural gas leakages as it was also shown by studies in the United Kingdom and the United States (Derwent et al., 1995; Derwent et al., 2000; Choi and Ehrmann, 2004). The high toluene concentration in profile \#4 and the apparently enhanced emissions in the afternoon point to industrial activities. Since also evaporative losses from gasoline might be higher in the afternoon due to higher temperatures, we interpret this profile as a mixture
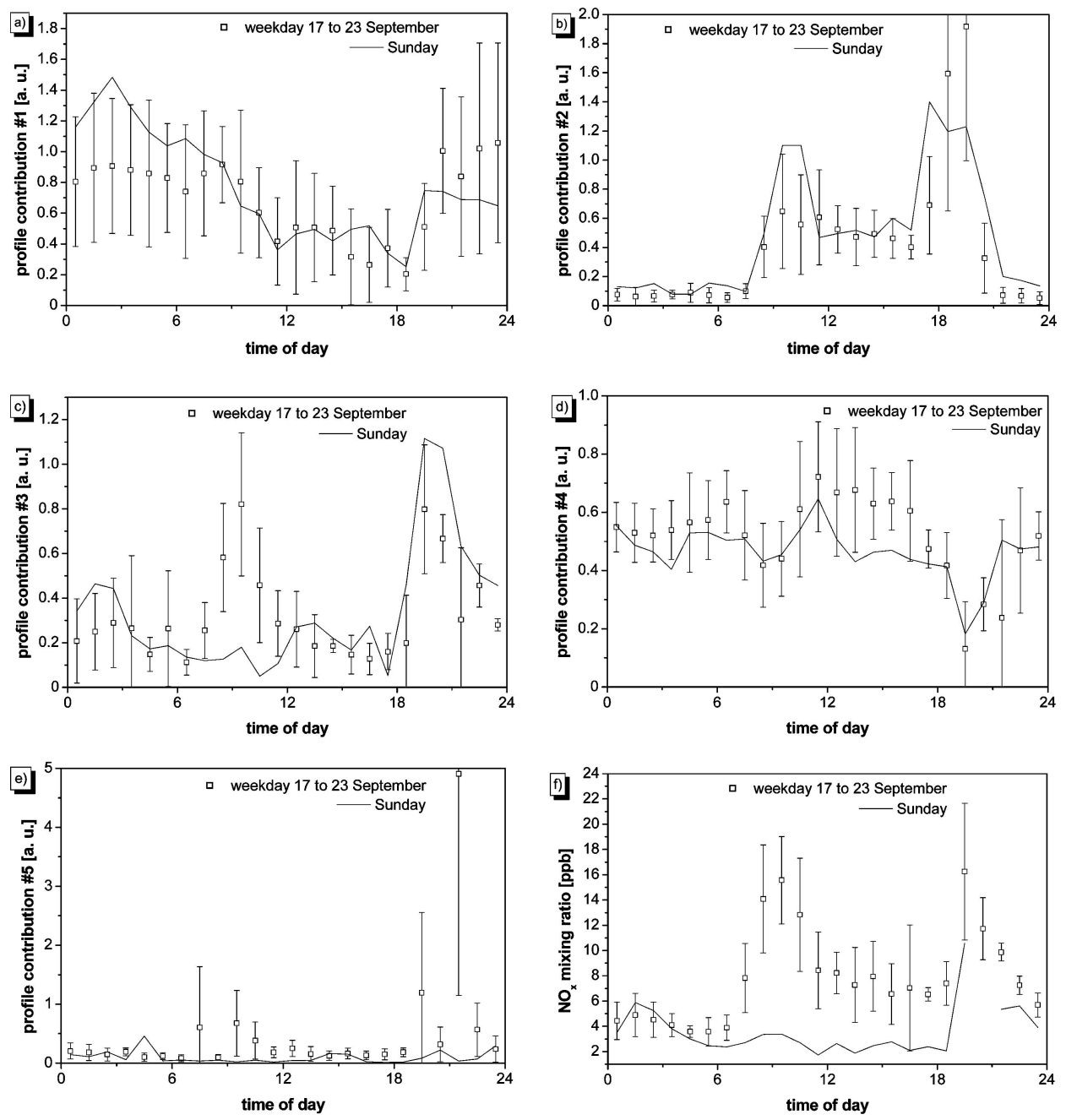

Figure 11. Diurnal cycles of the profile contributions \#1 to \#5 and $\mathrm{NO}_{x}$ during September 2003 at Verzago. 'Weekday 17 to 23 September' reflects the data from Wednesday 17 to Friday 19 and Monday 22 to Tuesday 23. 'Sunday' represents the data on 21 and 28 September. Vertical bars represent the standard deviations of the mean. Due to the small number of data, no variability is shown for Sunday data. 
of industrial activities (solvent use, combustion) and partly non-tailpipe emissions (evaporation) of gasoline. In summary, the 5 different profiles could be reasonably related to different processes: profile \#1 (natural gas), profile \#2 (biogenic impact), profile \#3 (vehicle exhaust), profile \#4 (industry; solvent use and combustion, nontailpipe evaporation), profile \#5 (cyclohexane).

Figure 11 shows the diurnal cycles of the profile contributions and $\mathrm{NO}_{x}$, separated into weekday and Sunday data. For the weekday data, average diurnal cycles were calculated for the period from September 17 to 23 as the meteorological conditions for this period were similar to the meteorological conditions on the two Sundays. Substantial differences occurred for profile \#5 as the cyclohexane peaks were only detected on weekdays and less significantly for profile \#4 during the daytime hours as the industrial influence ceased on Sundays. For profile \#3 and $\mathrm{NO}_{x}$ (a marker for combustion processes, especially diesel vehicles) a considerable difference was found in the morning hours whereas no clear difference appeared in the evening hours for the two selected periods. This agrees with the analyses of Blanchard and Tanenbaum (2003) for $\mathrm{NO}_{x}$, benzene, and toluene mixing ratios on Sundays and weekdays. Our findings are also in line with traffic statistics in Milan for summer months (Agenzia Regionale per la Protezione dell' Ambiente della Lombardia Dipartimento, Milan), which show that for four counting locations there are on average 3.3 times more cars ( $<7 \mathrm{~m}$ length) on weekdays than on Sundays in the morning, but only 1.4 times more in the evening. The number of trucks and busses $(>14 \mathrm{~m})$ is even reduced a factor of 5.5 in the morning and 2.4 in the evening. This implies that the various weekday to Sunday differences in both the profile contribution \#3 and the $\mathrm{NO}_{x}$ mixing ratios are driven by different traffic densities.

\section{Conclusions}

Three measurement campaigns within a period of 5 years were performed in the Po Basin in early summer 1998, summer 2002, and autumn 2003. Measurements of aromatic compounds at Verzago showed a recurrent feature with enhanced toluene peaks without enhanced concentrations of benzene at around noontime. Closely correlated benzene to toluene ratios in car exhausts and the absence of toluene peaks during weekends and the holiday period in summer pointed to an advection of industrially released toluene. Different toluene to benzene ratios on weekends compared to weekdays as well as in August compared to July and September enabled us to identify a 'weekend effect' and a 'vacation (ferragosto) effect', respectively.

Cyclohexane measurements revealed another anthropogenic impact at the semirural sampling site. Distinct peaks appeared between 9 and 10 PM under northerly winds and wind speeds between 2 and $3 \mathrm{~m} / \mathrm{s}$. No peaks were observed on Saturdays and Sundays.

A multivariate receptor model analysis for the semi-rural site in 2003 distinguished five different concentration profiles that could be reasonably attributed to natural gas, biogenic impact, vehicle exhaust, industrial activities, and a single 
cyclohexane source. Diurnal cycles of the profile contribution showed characteristic differences on weekdays and Sundays. The vehicle exhaust profile contribution was in line with traffic statistics and could be reasonably explained by traffic densities.

The selected VOCs presented here and in a companion paper (Steinbacher et al., 2005) illustrated the anthropogenic and biogenic impact on the ambient trace gas levels in the Po Basin. These detailed analyses will provide a good basis within the FORMAT project to investigate the production of formaldehyde from different VOCs and the role of formaldehyde as an intermediate of the VOC oxidation in the boundary layer. By means of the present VOC patterns, it should be possible to elucidate the contributions to the $\mathrm{HCHO}$ formation of certain VOCs, to specify the main $\mathrm{HCHO}$ precursors, and to distinguish and to quantify the different formation mechanisms of formaldehyde: primary emissions, secondary formation from anthropogenic and secondary formation from biogenic precursors.

\section{Acknowledgments}

We thank the PIPAPO and FORMAT crews, the Direzione Generale Qualità dell'Ambiente of the Regione Lombardia and the Agenzia Regionale per la Protezione dell' Ambiente della Lombardia Dipartimento, sub-provinciale Citta di Milano for providing data. This work was supported by the Swiss National Science Foundation under Grant No. 21-61573.00. The FORMAT project was funded by the Research Directorate of the European Commission under Grant No. EVK2-CT2001-00120 and by the Federal Office for Education and Science in Switzerland, BBW nr. 01.0233.

\section{References}

Bardeschi, A., Colucci, A., Gianelle, V., Gnagnetti, M., Tamponi, M., and Tebaldi, G., 1991: Analysis of the impact on air quality of motor vehicle traffic in the Milan urban area, Atmospheric Environment 25B(3), 415-428.

Blanchard, C. L. and Tanenbaum, S. J., 2003: Differences between weekday and weekend air pollutant levels in Southern California, Journal of the Air \& Waste Management Association 53, 816828.

Borbon, A., Fontaine, H., Locoge, N., Veillerot, M., and Galloo, J. C., 2003: Developing receptororiented methods for non-methane hydrocarbon characterization in urban air - part I: source identification, Atmospheric Environment 37, 4051-4064.

Brocco, D., Fratarcangeli, R., Lepore, L., Petricca, M., and Ventrone, I., 1997: Determination of aromatic hydrocarbons in urban air of Rome, Atmospheric Environment 31(4), 557566.

Brönnimann, S. and Neu, U., 1997: Weekend-weekday Differences of Near-Surface Ozone Concentrations in Switzerland for Different Meteorological Conditions, Atmospheric Environment 31(8), $1127-1135$.

Carter, W. P. L., 1994: Development of ozone reactivity scales for volatile organic compounds, Journal of the Air \& Waste Management Association 44, 881-899. 
Ciccioli, P., Brancaleoni, E., and Frattoni, M., 1999: Reactive Hydrocarbons in the Atmosphere at Urban and Regional Scales, in Reactive Hydrocarbons in the Atmosphere, edited by C. N. Hewitt, pp. 159-207, Academic Press, San Diego.

Choi, Y.-J. and Ehrmann, S. H., 2004: Investigation of sources of volatile organic carbon in the Baltimore area using highly time-resolved measurements, Atmospheric Environment 38, 775791.

Christensen, C. S., Skov, H., and Palmgren, F., 1999: C5-C8 non-methane hydrocarbon measurements in Copenhagen: concentrations, sources and emission estimates, The Science of the Total Environment 236, 163-171.

Derwent, R. G., Davies, T. J., Delaney, M., Dollard, G. J., Field, R. A., Dumitrean, P., Nason, P. D., Jones, B. M. R., and Pepler, S. A., 2000: Analysis and interpretation of the continuous hourly monitoring data for $26 \mathrm{C}_{2}-\mathrm{C}_{8}$ hydrocarbons at 12 United Kingdom sites during 1996, Atmospheric Environment 34, 297-312.

Derwent, R. G., Middleton, D. R., Field, R. A., Goldstone, M. E., Lester, J. N., and Perry, R., 1995: Analysis and interpretation of air quality data from an urban roadside location in central london from the period from July 1991 to July 1992, Atmospheric Environment 29(8), 923946.

Diem, J. E., 2000: Comparisons of weekday-weekend ozone: Importance of biogenic volatile organic compound emissions in the semi-arid southwest USA, Atmospheric Environment 34, 34453451.

Dommen, J., Prévôt, A. S. H., Baertsch-Ritter, N., Maffeis, G., Longoni, M. G., Grüebler, F. C., and Thielmann, A., 2003: High-resolution emission inventory of the Lombardy region: development and comparison with measurements, Atmospheric Environment 37, 4149-4161.

Dommen, J., Prévôt, A. S. H., Neininger, B., and Bäumle, M., 2002: Characterization of the photooxidant formation in the metropolitan area of Milan from aircraft measurements, Journal of Geophysical Research 107(D22), art.-nr.: 8197, 10.1029/2000JD000283.

Friedrich, R. and Obermeier, A., 1999: Anthropogenic Emissions of Volatile Organic Compounds. In C. N. Hewitt, Reactive Hydrocarbons in the Atmosphere, Academic Press, San Diego, pp. 2-39.

Fujita, E. M., 2001: Hydrocarbon source apportionment for the 1996 Paso del Norte Ozone Study, The Science of the Total Environment 276, 171-184.

Fujita, E. M., Watson, J. G., Chow, J. C., and Magliano, K. L., 1995: Receptor Model and Emissions Inventory Source Apportionments of Nonmethane Organic Gases in California's San Joaquin Valley and San Francisco Bay Area, Atmospheric Environment 29(21), 3019-3035.

Grüebler, F. C., 1999: Reactive hydrocarbons in the Milan area: Results from the PIPAPO campaign. $\mathrm{PhD}$ Thesis. Institute for Atmospheric Science, Swiss Federal Institute of Technology Zurich.

Guerra, G., Iemma, A., Lerda, A., Martines, C., Salvi, G., and Tamponi, M., 1995: Benzene emissions from motor vehicle traffic in the urban area of Milan: Hypothesis of health impact assessment, Atmospheric Environment 29(23), 3559-3569.

Haagen-Smit, A. J., 1952: Chemistry and Physiology of Los Angeles Smog, Industrial and Engineering Chemistry 44(6), 1342-1346.

Heeb, N. V., Forss, A.-M., Bach, C., Reimann, S., Herzog, A., and Jäckle, H. W., 2000: A comparison of benzene, toluene and $\mathrm{C} 2$-benzenes mixing ratios in automotive exhaust and in the suburban atmosphere during the introduction of catalytic converter technology to the Swiss Car Fleet, Atmospheric Environment 34, 3103-3116.

Heuss, J. M., Kahlbaun, D. F., and Wolff, G. T., 2003: Weekday/Weekend Ozone Differences: What can we learn from Them?, Journal of the Air \& Waste Management Association 53, 772-788.

Jenkin, M. E., Davies, T. J., and Stedman, J. R., 2002: The origin and day-of-week dependence of photochemical ozone episodes in the UK, Atmospheric Environment 36, 999-1012.

Kalberer, M., Paulsen, D., Sax, M., Steinbacher, M., Dommen, J., Prévôt, A. S. H., Fisseha, R., Frankevich, V., Zenobi, R., and Baltensperger, U., 2004: Identification of polymers as major components of atmospheric organic aerosols, Science 303, 1659-1662. 
Konrad, S. and Volz-Thomas, A., 2000: Characterization of a commercial gas chromatography-flame ionization detection system for the in situ determination of $\mathrm{C}_{5}-\mathrm{C}_{10}$ hydrocarbons in ambient air, Journal of Chromatography A 878, 215-234.

Latella, A., Stani, G., Cobelli, L., Duane, M., Junninen, H., Astorga, C., and Larsen, B. R., 2005: Semicontinuous GC Analysis and Receptor Modelling for Source Apportionment of Ozone Precursor Hydrocarbons in Bresso, Milan 2003, Journal of Chromatography A 1071, 29-39.

Marr, L. C. and Harley, R. A., 2002: Spectral analysis of weekday-weekend differences in ambient ozone, nitrogen oxide, and non-methane hydrocarbon time series in California, Atmospheric Environment 36, 2327-2335.

Neftel, A., Spirig, C., Prévôt, A. S. H., Furger, M., Stutz, J., Vogel, B., and Hjorth, J., 2002: Sensitivity of photooxidant production in the Milan Basin: An overview of results from a EUROTRAC-2 Limitation of Oxidant Production field experiment, Journal of Geophysical Research 107(D22), art.-nr.: 8188, 10.1029/2001JD001263.

NIST Chemistry webbook, 2004: http://webbook.nist.gov/chemistry/pa-ser.html.

Paatero, P., 1997: Least squares formulation of robust non-negative factor analysis, Chemometrics and Intelligent Laboratory Systems 37, 23-35.

Paatero, P. and Tapper, U., 1994: Positive matrix factorization: A non-negative factor model with optimal utilization of error estimates of data values, Environmetrics 5, 111-126.

Prévôt, A. S. H., Staehelin, J., Kok, G. L., Schillawski, R. D., Neininger, B., Staffelbach, T., Neftel, A., Wernli, H., and Dommen, J., 1997: The Milan photooxidant plume, Journal of Geophysical Research 102(D19), 23375-23388.

Seinfeld, J. H. and Pandis, S. N., 1998: Atmospheric Chemistry and Physics: From Air Pollution to Climate Change, John Wiley \& Sons, Inc., New York, pp. 1326.

Sagebiel, J. C., Zielinska, B., Pierson, W. R., and Gertler, A. W., 1996: Real-world emissions and calculated reactivities of organic species from motor vehicles, Atmospheric Environment 30(12), 2287-2296.

Spirig, C., Neftel, A., Kleinman, L. I., and Hjorth, J., 2002: $\mathrm{NO}_{x}$ versus VOC limitation of $\mathrm{O}_{3}$ production in the Po valley: local and integrated view based on observations, Journal of Geophysical Research 107(D22), art.-nr.: 8191, 10.1029/2001JD000561.

Staehelin, J., Keller, C., Stahel, W., Schläpfer, K., and Wunderli, S., 1998: Emission Factors from Road Traffic from a Tunnel Study (Gubrist Tunnel, Switzerland). Part III: Results of Organic Compounds, $\mathrm{SO}_{2}$ and Speciation of Organic Exhaust Emissions, Atmospheric Environment 32(6), 999-1009.

Staffelbach, T., Neftel, A., Blatter, A., Gut, A., Fahrni, M., Staehelin, J., Prévôt, A. S. H., Hering, A. M., Lehning, M., Neininger, B., Bäumle, M., Kok, G. L., Dommen, J., Hutterli, M., and Anklin, M., 1997: Photochemical oxidant formation over southern Switzerland. 1. Results from summer 1994, Journal of Geophysical Research 102(D19), 23345-23362.

Steinbacher, M., Dommen, J., Ordóñez, C., Reimann, S., Staehelin, J., Andreani-Aksoyoglu, S., and Prévôt, A. S. H., 2005: Volatile organic compounds in the Po Basin. Part B: biogenic VOCs, Journal of Atmospheric Chemistry 51, 293-315.

Steinbacher, M., Dommen, J., Ammann, C., Spirig, C., Neftel, A., and Prévôt, A. S. H., 2004: Performance characteristics of a proton-transfer-reaction mass spectrometer (PTR-MS) derived from laboratory and field measurements, International Journal of Mass Spectrometry 239, 117128.

Thielmann, A., Prévôt, A. S. H., Grüebler, F. C., and Staehelin, J., 2001: Empirical ozone isopleths as a tool to identify ozone production regimes, Geophysical Research Letters 28(12), 23692372.

Thielmann, A., Prévôt, A. S. H., and Staehelin, J., 2002: Sensitivity of ozone production derived from field measurements in the Italian Po basin, Journal of Geophysical Research 107(D22), art.-nr.: 8194, 10.1029/2000JD000119. 
Watson, J. G., Chow, J. C., and Fujita, E. M., 2001: Review of volatile organic compound source apportionment by chemical mass balance, Atmospheric Environment 35, 1567-1584.

Winkler, J., Blank, P., Glaser, K., Gomes, J. A. G., Habram, M., Jambert, C., Jaeschke, W., Konrad, S., Kurtenbach, R., Lenschow, P., Lörzer, J. C., Perros, P. E., Pesch, M., Prümke, H. J., Rappenglück, B., Schmitz, T., Slemr, F., Volz-Thomas, A., and Wickert, B., 2002: Ground-based and airborne measurements of nonmethane hydrocarbons in BERLIOZ: Analysis and selected results, Journal of Atmospheric Chemistry 42, 465-492. 